\title{
Measurement of Social Innovation at Organisation's Level: Theoretical Issues
}

\author{
Rasa Dainiené $\dot{1}^{1}$, Lina Dagiliené2 \\ ${ }^{1,2}$ Kaunas University of Technology
}

\begin{abstract}
The paper presents theoretical issues of social innovation measurement due to its multidimensional context. The purpose of this paper is to review the theoretical background on the topic of social innovation concept and TBL approach and to propose the conceptual model for measuring the value of social innovation at an organisation's level.

The proposed measurement process for social innovation consists of four stages, which cover selection and implementation of the social innovation, identification of the scope of the social innovation, measurement and calculation of the consolidated index. Indicators for measurement value of social innovation are applied using the TBL approach. The conceptual model could be applied as a methodology for measuring value of social innovation.
\end{abstract}

Keywords - Measurement, organisation, social innovation, triple bottom line approach.

\section{INTRODUCTION}

The relevance of social innovation has grown since the year 2000 and attracts particular attention from global and national policy makers, researchers, business and society. All of them achieve common social goals in addressing global issues such as: climate change and global warming, demographic changes, lack of natural resources and energy usage, consumerism, health and poverty. Social innovation is one of the appropriate instruments to deal with deep routed problems related to solving of the growing demographic, social and environmental problems. The development of the social innovation helps solve social needs through open innovations, social movements, legislation, new or improved technologies, products, processes or services, etc.

The governments, NGOs and academics of Europe and the rest of the world are developing strategies, programmes, pilot projects and performing studies regarding social innovations. Different organisations such as Organisation for Economic Cooperation and Development (OECD), National Endowment for Science, Technology and the Arts (NESTA), Programme for International Student Assessment (PISA), Centre for Social Innovation (CSI) and other are seeking to clarify the main social needs, identify appropriate metrics, indices and construct the social innovation measurement frameworks and tools.

Most of the constructed approaches/studies for measurement of the social innovation are known at the national and regional levels (Dainienè \& Dagilienè, 2015):

\footnotetext{
${ }^{1}$ TEPSIE - The Theoretical, Empirical and Policy Foundations for Building Social Innovation in Europe.
}

- Measurement tool "European Public Sector Innovation Scoreboard" (EPSIS, 2013) provided by the European Commission;

- TEPSIE $^{1}$ project (2014) introduced the "Integrated model for measuring social innovation";

- INNOBASQUE provided research "Regional Social Innovation Index" (Resindex, 2013);

- Pilot methodology project of Vision - "European Social Innovation Index" (2011);

- Project "Australian Public Sector Innovation Indicators" (APSII, 2013);

- NESTA, MEPIN ${ }^{2}$, Innobarometer, EPSIS, etc. introduced questionnaires for measurement of innovations in the public sector;

- Tool to assess the African Social Development Index (ASDI, 2014).

As mentioned by Dainienè \& Dagilienè (2015), the social innovation is multidimensional. Social innovation may possess multiple dimensions, such as new product and services for healthier and safer life, technological process for minimising a negative impact on environment, etc. Due to this reason, researchers meet the challenge of creating an overall unified approach for measuring value of social innovation (Krlev et al., 2014). The main problem during the development of such approaches is also related to the lack of qualitative and quantitative databases, which contain various social indicators (TEPSIE, 2012-2014; Resindex, 2013; Spila et al., 2013; Vision's, 2011). Thus, the next challenge is the identification of sets of indicators for measurement value of social innovation.

The overview of scientific literature has demonstrated that a triple bottom line (TBL) approach is often used to measure sustainability development at an organisation's level (Elkington, 1997; Norman \& MacDonald, 2004; Hubbard, 2009; Godfrey \& Manikas, 2012; Habib \& Bahar, 2014). According to Elkington (1999), Higgins (2001) and Slater \& Gilbert (2004), the TBL conception has a particular value as a potential framework in the first decade of the 21 st century.

Vavra et al. (2011) noted that companies have a lack of experience to evaluate environmental and social aspects of their products and innovation projects.

These insights not only highlight needs in the field of research and public sector but also enhance practitioners to understand importance and impact of social innovations on 
organization's activity, paying special attention to the ability to measure it.

To fill this gap, the paper seeks to answer the following research question: How to measure the value of social innovation at an organization's level by adapting different approaches and methodologies?

The purpose of this paper is to review the theoretical background on the topic of social innovation concept by using the TBL approach and to propose the conceptual model for measuring the value of social innovation at an organisation's level.

This paper contributes to the scientific literature by adapting the TBL approach to the measurement of social innovation and proposing a conceptual model at an organisation's level.

\section{CONCEPT OF SOCIAL INNOVATION}

Two main criteria - novelty and improvement - are needed to describe innovation (Ims \& Zsolnai, 2014). Thus, social innovation includes social aspects and may be defined as innovative activities and services that are motivated by the goal of meeting a social need and predominantly diffused through organisations whose primary purposes are social (Mulgan, 2006). Phills et al. $(2008,39)$ determine social innovation as "a novel solution to a social problem that is more effective, efficient, sustainable or just than existing solutions, and for which the value created accrues primarily to society as a whole rather than private individuals". It can be "a product, production process or technology, but it can also be a principle, and idea, a piece of legislation, a social movement, an intervention or some combination of them". As noted by Bund et al. (2015), there is still no general definition of social innovation. The term "social innovation" characterises societal transformations, the development of new products, services and programmes, organisational management, social entrepreneurship, as well as a model of governance and empowerment.

Guide to SI (2013) introduces the following six societal trends:

- demography trend - covers migration and ageing of population aspects;

- environmental trend - includes water, climate change and energy, etc.;

- new community trend - covers diversity and new community providing IT solution aspects;

- poverty related trend such as poverty, social exclusion and child poverty;

- health and well-being trend - includes health inequities, happiness and care;

- ecological goods and services trend - includes fair trade and local production aspects.

The concept of social innovation at an organisation's level is a complex multidimensional mechanism and may be characterised through financing, consumer and process factors (Fig. 1).

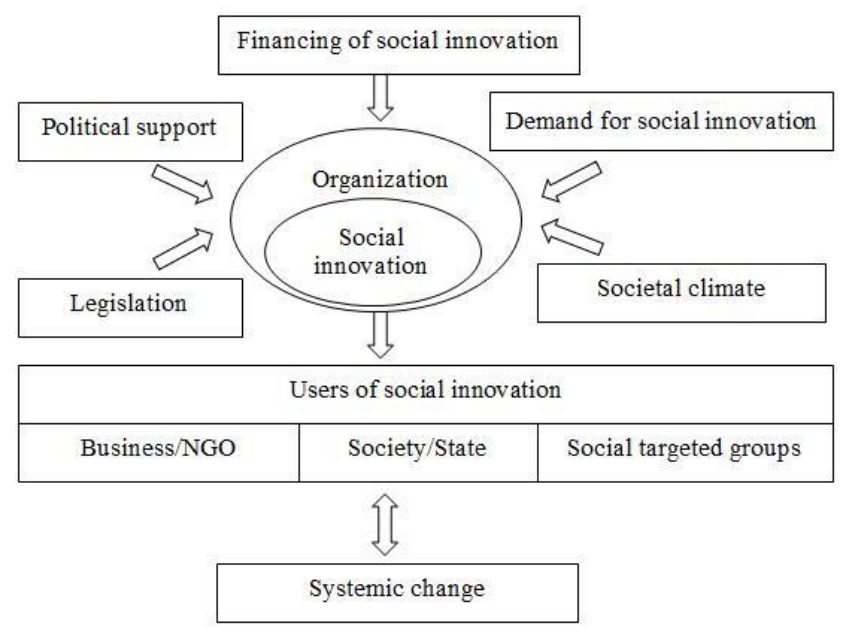

Fig. 1. Interaction of social innovation at an organisation's level.

The organisation is also influenced by the other external factors: political support, legislation, societal climate and growing demand of social innovation (Krlev et al., 2014). The link between an organisation and outlined external factors is important and influencing but it has not been further analysed in this context.

The process of innovation is complex and consists of four main stages (Social Innovation Europe Initiative, 2011; Reeder et al., 2012; Guide to Social Innovation, 2013): 1) ideas; 2) prototyping and piloting; 3) implementation; 4) scaling. Other authors (Murray et al., 2010; TEPSIE, 2012) present a wider range of six stages: 1) prompts; 2) proposals; 3) prototypes; 4) sustaining; 5) scaling; 6) systemic change. The life cycle of social innovation consists of the stages mentioned above and includes additional social elements.

The stage of prompts, inspirations and diagnoses includes all the factors, which identify the needs for social innovation (crisis, public spending cuts, poor performance, new technologies, etc.). The stage of proposals and ideas involves generating a new idea that provides proposition to the identified need. The stage of prototyping and pilots is the phase of testing the idea in practice. Sustaining means developing an economic business model, which will ensure the venture's financial future. The stage of scaling and diffusion contains some number of strategies, which enable a particular innovation to grow, extend and disseminate (Murray et al., 2010; TEPSIE, 2012). As noted by Murray et al. (2010), the systemic change stage is the primary purpose of social innovation. Systemic innovation usually covers changes in sectors such as public, private, grant economy and household. It is important to note that the process of systemic change or systemic innovation takes a longer period.

Every stage for activities needs the different type of investment. Because of high level of risk and uncertain reward, social innovation needs public support especially in early stages. The private investment is more useful in the implementation and scaling stage. Business plans are drawn up and a more approximate vision of the future directions is outlined in these stages. 
Social innovative solutions need resources of finance, which share and align with their social mission (Murray et al., 2009, 2010; The Young Foundation, 2012). For development and implementation of social innovation, organisations can use a wide range of funding. In Europe, the methods of the financing of social innovation are (SIE, 2012):

- various instruments introduced by the European Commission encouraging the process of empowering community and organisations for resolving social problems;

- social banks;

- commercial investment funds;

- social investment funds;

- innovation funds;

- venture philanthropy funds.

By examining effects of social innovation, Černikovaite \& Laužikas (2011) presented three groups of the end-users of social innovation:

- the social targeted groups (students, pupils and educational institutions, research and development organisations, aged or disabled people, social exclusion groups, working people with low incomes, volunteers, social workers, retired professionals, public administration organisations and others);

- the social business / non-governmental organisations (NGOs);

- State and society (social policy, assistance).

Social innovation value includes economic, environmental and social aspects. Thus, we assume that various measurement indicators used for the above-mentioned sustainability dimensions may be applied to social innovations.

\section{BASICS OF TRIPLE BOTTOM LINE}

J. Elkington introduced the sustainability idea as a "triple bottom line" (TBL) around 1997. The TBL emerged as a new accounting framework that incorporates three dimensions of organisation's activity: social, environmental and financial (Slaper \& Hall, 2011; Hubbard, 2009). According to Hubbard $(2009,80)$, the TBL "is based on the idea that a firm should measure its performance in relation to stakeholders including local communities and governments, not just those stakeholders with whom it has direct, transactional relationships (such as employees, suppliers and customers)". The TBL is measuring the impact of an organisation's activities, including its profitability, shareholder values and its social, human and environmental capital (Savitz \& Weber, 2006).
Indicators of TBL dimensions aim at assessing the organisation's impact on people, environment (planet) and economic profit. Table I presents the examples of indicators of TBL dimensions according to Elkington (1998), Slaper \& Hall (2011).

There are no established general sets of indicators suitable for all organisations. Depending on an organisation's performance and a type of social innovation activity, every organisation can construct or purchase a suitable set of TBL indicators.

\section{APPROACHES FOR SOCIAL INNOVATION MEASUREMENT AT ORGANISATION'S LEVEL}

Social entrepreneurs, social innovators and third sector organisations are discussing about the social innovations for more than 10 years. Non-profits executives, police makers, funders and others are very interested in the measurement of the value of a funded social innovation. It isn't enough for organisation to create the value by implementing the social innovation, but also is increasing the need to measure it at organisation's level.

Common approaches for the measurement of the value of the social innovation at an organisation's activities are (Rosenzweig, 2004; TEPSIE, 2014):

- Social Return on Investment (SROI);

- Social Reporting Standard (SRS);

- Social Cost Benefit Analysis (SCBA);

- Randomized Control Trials (RCTs);

- Theories of Change;

- Balanced Scorecard (BSc);

- Acumen Fund Scorecard;

- Social Return Assessment;

- AtKisson Compass Assessment;

- Ongoing Assessment of Social Impact (OASIS);

- Poverty and Social Impact Analysis (PSIA);

- and others.

The mentioned approaches/methods for the measurement of the social innovation are mostly assigned to double bottom line concept (Rosenzweig, 2004). The proposed conceptual framework for measurement the value of the social innovation includes the triple bottom line approach and covers economic, social and environmental dimensions.

By applying the artificial intelligence/heuristic (like fuzzy logic) computation approaches arises the opportunity to consolidate the different types of indicators.

TABLE I

EXAMPLES OF INDICATORS OF TBL DIMENSIONS

\begin{tabular}{|l|l|}
\hline TBL dimension & Indicators \\
\hline Social & $\begin{array}{l}\text { Community relations, product safety, training and education initiatives, sponsorship, charitable donations of money and time, as well as } \\
\text { employment of disadvantaged groups, etc. }\end{array}$ \\
\hline Environmental & $\begin{array}{l}\text { Trends in legal compliance, provisions for fines, insurance and other legally related costs, landscaping, remediation, decommissioning } \\
\text { and abandonment costs, the number of public complaints, the life-cycle impacts on products, energy, materials and water usage at } \\
\text { production sites, polluting emissions, environmental hazards and risks, waste generation, consumption of scarce natural capital, etc. }\end{array}$ \\
\hline Financial & $\begin{array}{l}\text { Profit and loss, accounting of the organisation's costs of the demand for its products or services, its pricing and profit margins, its } \\
\text { innovation applications, etc. }\end{array}$ \\
\hline
\end{tabular}




\section{RESEARCH METHODOLOGY}

The conceptual theoretical framework for measurement of the value of social innovation at an organisation's level uses the combination of different approaches and methodologies. The development of the conceptual framework contains several methodological stages:

- review of the scientific literature;

- identification of key measurement indicators of social innovation;

- analysis and comparison of international pilot studies and research projects;

- construction of logical relationship and graphical visualisation.

The systematic overview of the scientific publications and international pilot studies, research projects provided by the European Commission, OECD, Young Foundation, NESTA, $\mathrm{BEPA}^{3}$, APSII has been used to clarify the topic of social innovation and TBL approach. Theoretical background discloses the complexity of the social innovation concept and interaction with an organisation through external factors and stakeholders.

In relation to the theoretical framework, the applied set of TBL measurement indicators covers economic, environment and social dimensions. It has been proposed to use traditional indicators, specific indicators and indicators according to the Sustainability Reporting Guidelines (GRI, 2006) version G3 presented in Dainienè and Dagilienè (2015) research.

The conceptual framework for measuring social innovation includes four stages, starting from deployment of innovation in the organisation, identification of indices and measuring of potential social value created by innovation. The outcome of the developed theoretical framework is the unified index of the value of social innovation.

\section{RESULTS AND DISCUSSION}

The process of social innovation is complex, thus depending on the stage of social innovation lifecycle the purpose of measurement may be different. Therefore, value measurement is applied only to the final scaling stage of the innovation process.

The results after applying the social innovation are difficult to predict. To define inputs for the innovation is easy - they will always be resources and assets. The characterisation and prediction of outputs are very difficult if the innovation process is incomplete or even has not started yet. The outputs are more unpredictable if the innovation is large, complex because then they become nonlinear, risky, could contain aspects of serendipity (Gamal et al., 2011). Organisational outputs refer to measurable products that can be easily related to an organisation or an individual. Societal outcomes are harder to measure and connect them directly to specific organisation activities (Clark et al., 2004; Krlev et al., 2014).
For instance, APSII used such outcomes as societal and environmental impacts, quality efficiency and productivity, improved employee satisfaction, benefits for users and other intangible effects (e.g., trust and legitimacy) for measuring public sector innovation (EPSIS, 2013).

The conceptual framework for measurement of social innovation using the TBL approach is depicted in Fig. 2. The proposed model presents steps of measuring social innovation as a separate unit at an organisation's level.

This framework is designed on the basis of theoretical framework for measuring of the value of social innovation proposed by Dainienè and Dagilienè (2015). Conceptual framework is improved considering the stages of social innovation process and measuring it at an organisation's level. The measurement process of social innovation covers four stages which are described in Table II.

The first stage of the measurement process starts from the implementation of the selected social innovation in an organisation. The implementation of the social innovation in an organisation follows the main previous stages of innovation process. There should be pilot projects implemented and answers found to further financing questions by this time. Depending on circumstances, the innovation is applied inside or outside an organisation.

The second stage requires necessity of identification of the dimensions of the social innovation. Established dimensions (Ethical goods \& Services \& Responsibility, education, community, poverty, health and environment) reflect to social requirements fulfilled by the social innovation.

The third stage includes an appropriate set of indicators according to TBL dimensions and their value measurement. For the measurement of innovation in the economic and environmental dimensions, the applied set of indicators (Savitz \& Weber, 2006; Willard \& Elkington, 2002; Slaper \& Hall, 2011 ) is more traditional and common. The set of indicators of the environmental TBL dimension is used for identifying an influence of social innovation on these areas:

- air and water quality,

- energy consumption,

- eco-producing,

- product life cycle, etc

The measurement reflects a possible influence of the social innovation on natural resource vitality. It may help an organisation manage the impact on a project or policy (Slaper \& Hall, 2011). The set of indicators for measuring social innovation depends on expectations and requirements of organisation after determination of the dimension of innovation.

Depending on the category of social innovation, the set of appropriate indicators is applied for the measuring of innovation in social TBL dimension. The indicators may represent ethical goods, services responsibility, environment, community, education, health protection and poverty areas.

${ }^{3}$ BEPA - Bureau of European Policy Advisers. 


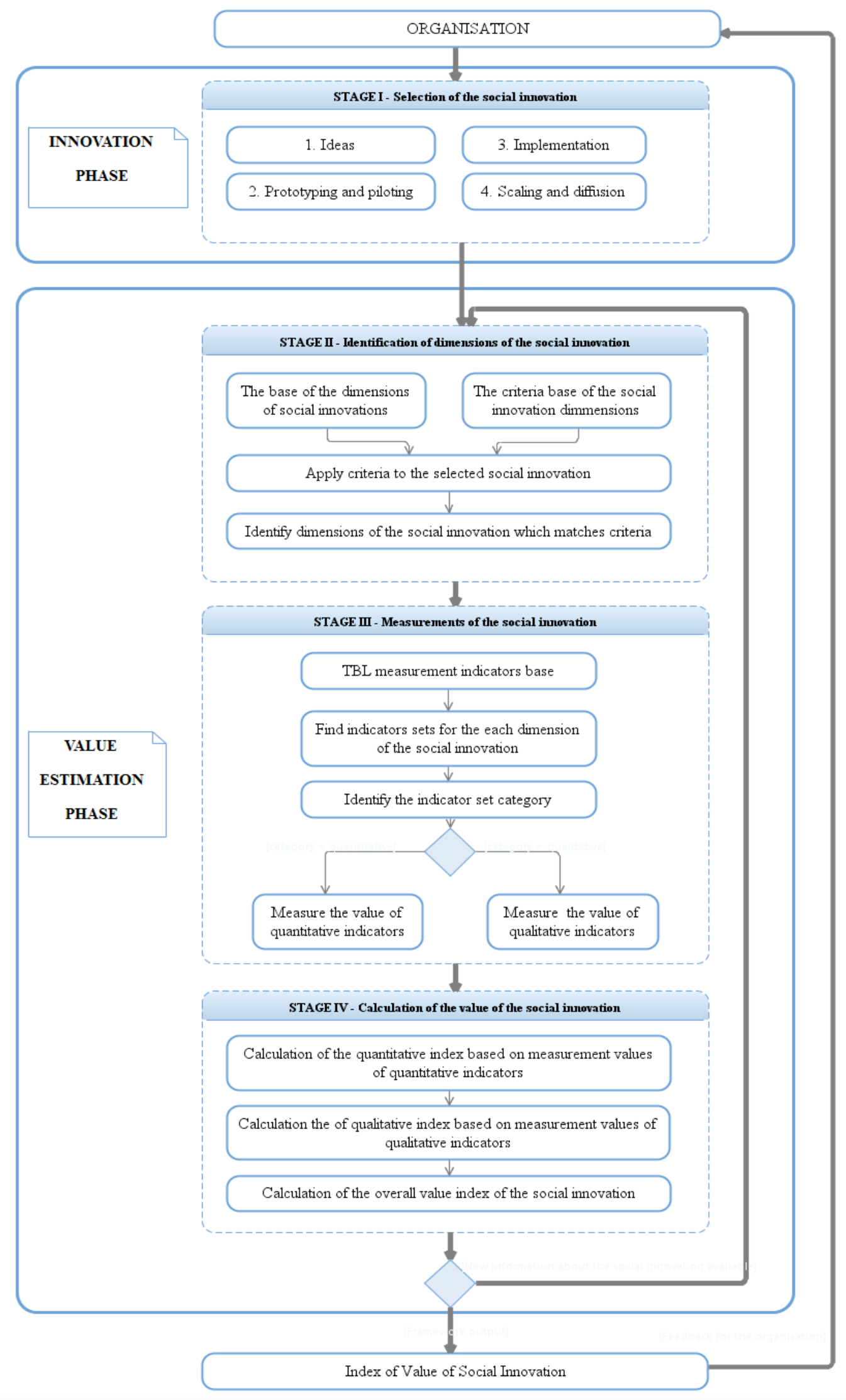

Fig. 2. The conceptual model for measuring the value of social innovation at an organisation's level. 
TABLE II

MEASUREMENT PROCESS OF THE VALUE OF SOCIAL INNOVATION

\begin{tabular}{|c|c|c|c|}
\hline Stage & Input & Output & Description \\
\hline I stage & $\begin{array}{l}\text { Ideas, concepts, } \\
\text { previous experience } \\
\text { used for a social } \\
\text { innovation } \\
\text { implementation. } \\
\text { Data from social } \\
\text { innovation process. }\end{array}$ & $\begin{array}{l}\text { Implementation of the } \\
\text { selected social } \\
\text { innovation. } \\
\text { The detailed information } \\
\text { (financial, social, } \\
\text { environmental and etc.) } \\
\text { about the implemented } \\
\text { social innovation. }\end{array}$ & $\begin{array}{l}\text { Selection of the concrete type of a social innovation (new product, process, etc.) and } \\
\text { implementation of this innovation inside or outside an organisation. }\end{array}$ \\
\hline II stage & $\begin{array}{l}\text { Information about } \\
\text { social innovation } \\
\text { (financial, social, } \\
\text { environmental and } \\
\text { etc.) } \\
\text { New criterions for } \\
\text { dimension of social } \\
\text { innovation } \\
\text { identification if they } \\
\text { are found. }\end{array}$ & $\begin{array}{l}\text { Identified dimensions of } \\
\text { social innovation which } \\
\text { matches criteria }\end{array}$ & $\begin{array}{l}\text { The artefacts of this stage are: } \\
\text { - The criteria base is collected for the social innovation dimensions identification. } \\
\text { The base of criterions is updated each time the new ones are received into a } \\
\text { framework. } \\
\text { The base of the social innovation dimensions which is used for identification of } \\
\text { the scope of social innovation due to key dimension and satisfaction of } \\
\text { stakeholder's needs. } \\
\text { The main purpose of this stage is to identify the social innovation dimensions which are } \\
\text { applicable to the selected social innovation (which was implemented in I stage). The } \\
\text { identification process is actually comparison of the social innovation information to the } \\
\text { criteria information and finding if it is matching the criteria of the appropriate social } \\
\text { innovation dimension or not matching. If it matches the criteria then dimension is } \\
\text { selected and added to the output result of the stage. }\end{array}$ \\
\hline III stage & $\begin{array}{l}\text { Dimensions of the } \\
\text { social innovation. } \\
\text { Accounting } \\
\text { information of the } \\
\text { social innovation. }\end{array}$ & $\begin{array}{l}\text { The values of the } \\
\text { indicators. }\end{array}$ & $\begin{array}{l}\text { The artefacts of this stage are: } \\
\text { - TBL measurement indicators base for each dimension of the social innovation. } \\
\text { - The classification of quantitative and qualitative indicators. } \\
\text { The main purpose of the stage is to measure the values for each set of indicators } \\
\text { represented by each social innovation dimension received in stage input. Measurements } \\
\text { can be quantitative or qualitative depending on the indicator type. The calculation } \\
\text { process itself can be various: from the mathematical equation to heuristic approach } \\
\text { usage in order to measure the value of the selected indicator. } \\
\text { The value of each indicator is added to the output result of the stage. }\end{array}$ \\
\hline IV stage & $\begin{array}{l}\text { The list of indicators } \\
\text { and their values. }\end{array}$ & $\begin{array}{l}\text { The value of the social } \\
\text { innovation. }\end{array}$ & $\begin{array}{l}\text { The artefacts of this stage are: } \\
\text { - The fuzzy rule bases used in calculation of each type of indexes mentioned below } \\
\text { i.e. the model of the stage. } \\
\text { The main purpose of this stage is calculation of the final consolidated index, which } \\
\text { represents the ultimate value of the concrete social innovation implemented at an } \\
\text { organisation's level. } \\
\text { This process consists of these steps: } \\
\text { - The calculation of quantitative index of the social innovation based on } \\
\text { measurement values of quantitative indicators. } \\
\text { The calculation of qualitative index of the social innovation based on } \\
\text { measurement values of quantitative indicators. } \\
\text { The calculation of the overall value index of the social innovation. } \\
\text { The calculation of all indexes is based on the heuristic approach which uses fuzzy } \\
\text { logic. Fuzzy logic approach is selected because it is one of the best approaches to } \\
\text { combine various types of the information (qualitative/quantitative, results of } \\
\text { questionnaires and etc.) and get the quantitative value out of that which already can be } \\
\text { interpreted from economic, social or etc. perspective Dainiene, Dagilienè (2013). }\end{array}$ \\
\hline
\end{tabular}

Some data of social and environmental metrics are collected at the state and national levels. Thus, it is very important to determine the set of appropriate indicators for measuring value of social innovation at an organisation's level.

Following the relation of the particular indicator to the social innovation, calculation of the unified index is performed in the fourth stage. The calculation of the final index of the value of social innovation is based on quantitative and qualitative indicators selected of appropriate social innovation. The fuzzy logic approach would be introduced for combining quantitative and qualitative information as introduced by Dainienè and Dagilienè (2013).
The fuzzy logic for index calculation is selected because it allows even approximately but effective to describe the behaviour of complex nonlinear dynamic systems, which usually have sophisticated description and analysis using classical mathematical equations. In general, the fuzzy logic model has these components: the fuzzification of inputs, the inference mechanism, that maps inputs to outputs with the rule base and the defuzzification of output fuzzy set for crisp output calculation (Passino \& Yurkovich, 1998). The fuzzy approach is highly used for solving risk management, economical, engineering and etc. problems. 
This unified index represents the value of the appropriate social innovation. The index reflects social and economic benefits of the implemented social innovation to potential endusers. Systemic change is the primary goal of the social innovation, which closely interacts with users of that social innovation. It represents long-term changes affecting communities or systems.

Responsible organisation improves its innovation activity considering meaning of the index and feedback from users.

The focus is dedicated to the measurement of social outputs and outcomes in three different TBL dimensions (economic, environmental and social) because of potential results such as changes in well-being. According to every dimension, the assessment of the index of social innovation triggers obtaining of its value and calculation of consolidated index.

The introduced framework is iterative and allows capability to repeat measurement process of the selected social innovation if new information about the social innovation is available which could affect the final index.

\section{CONCLUSION}

The article presents the theoretical framework for measurement of social innovation at an organisation's level.

The social innovation is a complex process, which requires various resources and assets for creating a new or improved product or process to satisfy social needs. For that reason, the measurement of the value of social innovation is applicable to the final stage of innovation implementation process.

We assume theoretically that the concept of social innovation refers to sustainability development, as it is one of the factors to foster the process. Thus, we use the TBL approach for measuring sustainability development and social innovation. The indicators of the TBL dimensions cover the outputs and outcomes of organisation's social innovation and measure the result by providing the final unified index of the value of the social innovation. The index of the value of social innovation represents the combined influence of organisation to tackle social needs.

The model for measuring the value of social innovation is iterative and can be applied once again to measure the value of the social innovation if new information is available about the social innovation.

Expected return of social innovation could be not only economic profit but also the decreased public costs of the issue of social problems. Possible return of social innovation is difficult to predict because innovation outcomes are difficult to calculate.

Systemic change is the primary purpose of social innovation. The measurement of social innovation process in the systemic change stage could be delayed due to result availability only in the long-term perspective. Until that time, social innovation will benefit from addressing problems and change of the existing system.

To assess positive benefits from the social innovation, it is recommended to measure social innovation and evaluate its impact on the ability to solve the social problems periodically.
The capability to measure the value of the social innovation could influence funding credibility, transferability stability, and social awareness of an organisation.

Verification of this framework in practice or evaluation using expert knowledge is the next step of the research.

\section{REFERENCES}

Bund, E., Gerhard, U., Hoelscher, M. \& Mildenberger, G. (2015). A Methodological Framework for Measuring Social Innovation. Historical Social Research, 40(3), 48-78.

http://dx.doi.org/10.12759/hsr.40.2015.3.48-78

Černikovaitè, M. L. \& Laužikas, M. (2011). The Model of Social Innovations in the Emerging Market of Lithuania. Intellectual Economics. 5(3(11)), 388-400. Retrieved from http://www.mruni.eu/lt/mokslo_darbai/ie/archyvas/dwn.php?id=299240

Dainienè, R. \& Dagilienè, L. (2015). A TBL Approach Based Theoretical Framework for Measuring Social Innovations. Procedia - Social and Behavioral Sciences. 20th International Scientific Conference "Economics and Management (ICEM-2015)", 213, 275-280. http://dx.doi.org/10.1016/j.sbspro.2015.11.537

Dainienè, R. \& Dagilienè, L. (2013). Company’s Going Concern Evaluation Fuzzy Model. Economics and management, 18(3), 374-382. http://dx.doi.org/10.5755/j01.em.18.3.3915

Elkington, J. (1998). Accounting for the Triple Bottom Line. Measuring Business Excellence, 2(3), 18-22. http://dx.doi.org/10.1108/eb025539

Elkington, J. (1997). Cannibals with Forks: The Triple Bottom Line of 21st Century Business. Oxford: Capstone.

European Commission. (2013). European Public Sector Innovation Scoreboard (EPSIS), A Pilot Exercise.

European Commission. (2012). Financing Social Impact Funding social innovation in Europe - mapping the way forward. Social Innovation Europe (SIE). Belgium: European Union. ISBN 978-92-79-22141-5. http://dx.doi.org/10.2769/31019

European Commission. (2013). Guide to Social Innovation. Regional and Urban Policy. Retrieved from http://ec.europa.eu/regional_policy/sources/ docgener/presenta/social_innovation/social_innovation_2013.pdf

Gamal, D., Salah, T. \& Elrayyes, N. (2011). How to measure organization Innovativeness? An overview of Innovation measurement frameworks and Innovation Audit/Management tools. Innovation support Department. TIEC.

GRI (Global Reporting Initiatives). (2006). Sustainability Reporting Guidelines. Version 3. Amsterdam, 2000-2006.

Godfrey, M. \& Manikas, A. (2012). Integrating triple bottom line sustainability concepts into a supplier selection exercise. Business Education and Accreditation, 4(1), 1-12.

Habib, A. \& Varqa, S. B. (2014). Introducing the Double Bottom Line (DBL) Measurement Approach for the Social Business Model and the Economic Valued Added (EVA) Theory as a Measure of Financial Sustainability. World Journal of Social Sciences, 4(3), 12-23. Retrieved from http://wjsspapers.com/static/documents/October/2014/2.\%20Adnan.pdf

Higgins, C. (2001). Triple bottom line reporting: The importance of consistency. In D. Birch \& J. Batten (Eds.), Paper presented to Governance and social responsibility in the new millennium, Deakin University, Burwood

Hubbard, G. (2009). Measuring Organizational Performance: Beyond the Triple Bottom Line. Business Strategy and the Environment, 18(3), 177-191. http://dx.doi.org/10.1002/bse.564

Kolk, A. (2003). Trends in sustainability reporting by the Fortune Global 250. Business Strategy and the Environment, 12, 279-291. http://dx.doi.org/10.1002/bse.370

Krlev, G., Bund, E. \& Mildenberger, G. (2014). Measuring What MattersIndicators of Social Innovativeness on the National Level. Information Systems Management, 31(3), 200-224. http://dx.doi.org/10.1080/10580530.2014.923265

Mulgan, G. (2006). The Process of Social Innovation. Innovations: Technology, Governance, Globalization, 1(2), 145-162. http://dx.doi.org/10.1162/itgg.2006.1.2.145

Murray, R., Caulier-Grice, J. \& Mulgan, G. (2009). Social Venturing. The Social Innovator Series, London: NESTA.

Murray, R., Caulier-Grice, J. \& Mulgan, G. (2010). The open book of social innovation. London: NESTA. Retrieved from http://www.nesta.org.uk/library/documents/Social_Innovator_020310.pdf 
Norman, W. \& MacDonald, C. (2004). Getting to the Bottom of "Triple Bottom Line". Business Ethics Quarterly, 14(2), 243-262. Retrieved from http://faculty.wwu.edu/dunnc3/rprnts.Getting\%20to\%20the\%20Bottom\% 20of\%20the $\% 20$ Triple\%20bottom\%20line.pdf

Passino, K. M. \& Yurkovich, S. (1998). Fuzzy Control. Addison Wesley Longman Inc. ISBN 0-01-18074-X.

Phills, J. A, Deiglmeier, K. \& Miller, D. T. (2008). Rediscovering social innovation. Stanford Social Innovation Review, 6(4), 34-43. Retrieved from http://ssir.org/articles/entry/rediscovering_social_innovation

Reeder, N., O'Sullivan, C., Tucker, S., Ramsden P. \& Mulgan, G. (2012) Strengthening Social Innovation in Europe. Journey to effective assessment and metrics (pp. 1-52). Belgium: European Union.

Rosenzweig, W., Clark, C., Long, D. \& Olsen, S. (2004). Double bottom line project: Assessing social impact in double bottom line ventures. Working paper 13, Berkeley, CA: Center for Responsible Business, University of California Berkeley.

Savitz, A. \& Weber, K. (2006). The Triple Bottom Line: how today's best-run companies are achieving economic, social and environmental success- and how you can too. San Francisco: Jossey-Bass.

Slaper, T. F. \& Hall, T. J. (2011). The Triple Bottom Line: What Is It and How Does It Work? Indiana Business Review, 86(1), 4-8. Retrieved from http://www.ibrc.indiana.edu/ibr/2011/spring/pdfs/spring2011.pdf

Slater, A. \& Gilbert, S. (2004). The Evolution of Business Reporting: Make Room for Sustainability Disclosure. Environmental Quality Management, 14(1), 41-48. http://dx.doi.org/10.1002/tqem.20024

The Young Foundation. (2012). Social Innovation Overview D1.1: A deliverable of the project: "The theoretical, empirical and policy foundations for building social innovation in Europe" (TEPSIE), European Commission - 7th Framework Programme, Brussels: European Commission, DG Research.

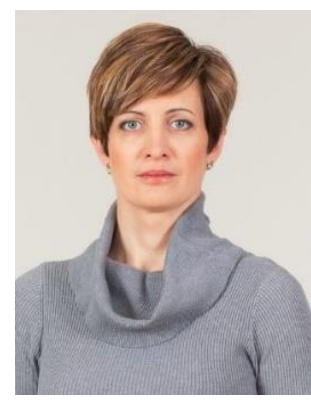

Rasa Dainienè received the Bachelor's degree in Economics from Kaunas Faculty of Humanities of Vilnius University, the Master's degree in Accounting from Kaunas University of Technology, Lithuania in 2011 and 2013, respectively.

At present, she is a Doctoral student at the Department of Accounting, the School of Economics and Business at Kaunas University of Technology. The area of her study is social innovations in the public sector concentrating on the measurement of the value of the social innovation.

Her recent publication is included in the Proceedings of the 20th International Scientific Conference "Economics and Management 2015".

Address: Kaunas University of Technology, 50-230 Gedimino, Kaunas, LT-44239, Lithuania

E-mail: rasa.dainiene@ktu.edu

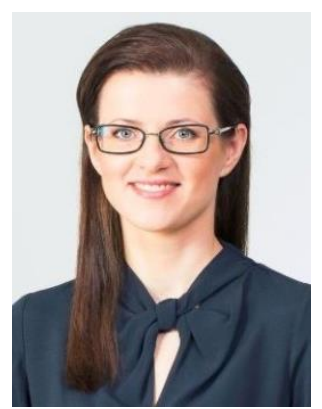

Lina Dagilienè is a Professor at the Accounting Department, Kaunas University of Technology. Lina gained her Doctoral degree in Social Sciences (Economics). Dagilienè has been actively exploring issues of sustainability accounting and reporting, social innovation and measurement issues. She is also interested in interdisciplinary dimensions due to accounting science.

She is an author of scientific monograph "Social Accounting: Theoretical Argumentation and Valuation" (2014). Other professional activities cover consulting, corporate training and project work. Lina Dagiliene is a member of the European Academy of Management (EURAM), Centre for Corporate Social Responsibility and European Accounting Association (EAA).

Address: Kaunas University of Technology, 50-208 Gedimino, Kaunas, LT-44239, Lithuania

E-mail: lina.dagiliene@ktu.lt 